\title{
In Vitro Estimation of Lead Content in Nepalese Traditional Ayurvedic Medicines Commonly Used in Children
}

\author{
Ojha $\mathbf{A}^{1}$ \\ ${ }^{1}$ Dr. Anil Ojha, MBBS, MD, Assistant Professor, \\ Department of Paediatrics, Kathmandu Medical College \\ and Teaching Hospital, Sinamangal, Kathmandu, Nepal.
}

\section{Introduction}

I Nepal before the start of allopathic medicine alternative or complementary medicine was practiced since a long time back. Still this complementary medicine is very popularly used in children. It encompasses treatment with vitamins and mineral supplement, homeopathy, herbal and ayurvedic medicines ${ }^{1}$. It is a common belief that these complementary medicines are safe and non toxic and are dispensed over the counter. Unfortunately this is not always true. Though many of these medicines are used safely there has been recent concern about its toxicity in some of these herbal preparations. The concern is the adulteration of these remedies with heavy metals like lead and arsenic due to poor quality control of the manufacturers of these products. Moreover there can be other toxic substances in these medicines which have not been studied yet.

The most concerning aspect of ayurvedic remedies is its adulteration by lead during its preparation. This is because lead gets absorbed more rapidly in children than in adults. This affects their developing nervous system causing developmental disorder and other side effects. Even low to moderate levels of lead have been associated with deleterious effects in children ${ }^{2}$. Recently there is a report from Reuters Health Information 2012 that the migrated Burmese children from refugee camps in Thailand to United States had dangerously high levels of lead in their blood. Researchers found that these children were given traditional remedies.

Our children from the neonatal period to adolescence are given ayurvedic medicine quite frequently despite of limited studies on the toxicological aspects of these medicines. We intend to address this

\begin{abstract}
Introduction: Ayurvedic remedies are popularly used in practice for long time in Nepal. It is regarded as safe and free from side effects. However there are published reports of the high content of heavy metals like lead in such preparations. No such study has been done in Nepal looking at the lead content in ayurvedic preparations. The aim of this study was to detect the level of lead in commonly used ayurvedic remedies used in paediatric population if any. Materials and Methods: Seventeen samples were selected for lead estimation based on frequency of prescription and over the counter dispense. All of them were analyzed using Atomic Absorption Spectrophotometer (AAS) 6300 using flame mode. Results: None of the samples had detectable level of lead in parts per billion. Conclusion: Though this study did not detect lead in the seventeen samples of ayurvedic medicine, a larger study is needed involving large samples of these medicines with use of more sensitive equipment for testing
\end{abstract}

Key words: Ayurvedic medicines, Complementary medicine

issue in one aspect by estimating the level of lead level in commonly used ayurvedic medicines in paediatric population in Nepal.

\section{Materials and Methods}

This was a cross sectional study. The study period was one month from $1^{\text {st }}$ October 2012 to $1^{\text {st }}$ November 2012. Eighteen samples of ayurvedic medicines were selected on their common use in clinical practice and over the counter prescription. The lists of the drugs are given below in Table 1.

Table 1: Ayurvedic drugs which were tested for lead content with their manufacture date and batch number.

\section{How to cite this article?}

Ojha A. In Vitro Estimation of Lead Content in Nepalese Traditional Ayurvedic Medicines Commonly Used in Children. J Nepal Paediatr Soc 2013;33(2):103-105. 
Table 1: List of ayurvedic products tested for lead

\begin{tabular}{|c|l|c|c|}
\hline S.N. & Products & $\begin{array}{c}\text { Batch } \\
\text { number }\end{array}$ & $\begin{array}{c}\text { Manufactured } \\
\text { date }\end{array}$ \\
\hline 1 & $\begin{array}{l}\text { Dabur } \\
\text { Chyawanprash }\end{array}$ & NB0083 & August 2012 \\
\hline 2 & $\begin{array}{l}\text { Patanjali } \\
\text { Chyawanprash }\end{array}$ & $\begin{array}{c}\text { Not } \\
\text { available }\end{array}$ & Not available \\
\hline 3 & $\begin{array}{l}\text { Gorkha } \\
\text { Chyawanprsh }\end{array}$ & available & Not available \\
\hline 4 & Makar Wajra & SB0047 & $\begin{array}{c}\text { November } \\
2012\end{array}$ \\
\hline 5 & $\begin{array}{l}\text { Swarna } \\
\text { Machikbhasma }\end{array}$ & 2 & June 2012 \\
\hline 6 & Colicarmin & 177 & March 2012 \\
\hline 7 & Smrittisagar rasa & S & April 2012 \\
\hline 8 & Yakrit Plihari & $31 / 77$ & $\begin{array}{c}\text { September } \\
2010\end{array}$ \\
\hline 9 & Arvindasava & BD0010 & July 2010 \\
\hline 10 & Livex & 285 & August 2010 \\
\hline 11 & Balamrit G syrup & 0167 & July 2012 \\
\hline 12 & Chitrakadi ghutika & B-4 & July 2012 \\
\hline 13 & Makaradhwaj & SB0077 & February 2012 \\
\hline 14 & Krimi Kuthar Rasa & E002 & May 2011 \\
\hline 15 & Janmaguthi & SB0430 & July 2012 \\
\hline 16 & Mriga Madasab & 0151 & August 2011 \\
\hline 17 & $\begin{array}{l}\text { Ashwagandha } \\
\text { Churna }\end{array}$ & 094 & $\begin{array}{c}\text { November } \\
2011\end{array}$ \\
\hline & & & \\
\hline
\end{tabular}

All the samples were analyzed at Department of Food Technology and Quality Control, Ministry of Agriculture and Cooperatives, Babarmahal, Kathmandu. The samples were encoded 69/CFL/3206 to 69/CFL/3223 and analyzed using Atomic Absorption Spectrophotometer (AAS) 6300. The flame mode was used during analysis. Using flame mode causes lesser atom excite as compared to graphite furnace analysis (GFA) causing lesser sensitivity in detecting the heavy metals. We used flame mode instead of GFA as the latter was not functioning in AAS.

Weighed 1-2 grams of each sample were kept in crucible and heated in a furnace at temperature of 500$600 \mathrm{C}$. The resulting ash is dissolved in 1:1 dilution of conc. hydrochloric acid and filtered and washed with distilled water to obtain a filtrate in volumetric flask. The filtrate is aspirated into the flame of AAS. The spectrophotometer analyzed the sample in parts per billion.

\section{Discussion}

Alternative medicine is in common practice in country like Nepal. However there are few studies looking at the contamination of these medicines by heavy metals like lead and its potential adverse effect

\section{Results}

Table 2: Test result for lead content in the ayurvedic medicines

\begin{tabular}{|c|l|c|}
\hline S.No. & Products & $\begin{array}{c}\text { Lead level in } \\
\text { Ppb }\end{array}$ \\
\hline 1 & Dabur Chyawanprash & Not detected \\
\hline 2 & Patanjali Chyawanprash & Not detected \\
\hline 3 & Gorkha Chyawanprsh & Not detected \\
\hline 4 & Makar Wajra & Not detected \\
\hline 5 & Swarna Machikbhasma & Not detected \\
\hline 6 & Colicarmin & Not detected \\
\hline 7 & Smrittisagar rasa & Not detected \\
\hline 8 & Yakrit Plihari & Not detected \\
\hline 9 & Arvindasava & Not detected \\
\hline 10 & Livex & Not detected \\
\hline 11 & Balamrit G syrup & Not detected \\
\hline 12 & Chitrakadi ghutika & Not detected \\
\hline 13 & Makaradhwaj & Not detected \\
\hline 14 & Krimi Kuthar Rasa & Not detected \\
\hline 15 & Janmaguthi & Not detected \\
\hline 16 & Mriga Madasab & Not detected \\
\hline 17 & Ashwagandha Churna & Not detected \\
\hline & & \\
\hline
\end{tabular}

on developing children. Lead is very toxic especially in young children. It has a direct toxic effect on haemopoetic and gastrointestinal system. Other organ like kidneys, liver, central and peripheral nervous system leading to anemia (sideroblastic), morphological changes in red blood cells, encephalopathy, abdominal pain, constipation and anorexia ${ }^{1}$.

The heavy metals like lead are added to ayurvedic medicines intentionally along with other elements like copper, gold, iron, mercury, silver, tin and zinc. Ayurveda believes that diseases results from imbalance of these elements. This is reason why these elements are added in the remedies. However these minerals are added after they have undergone a 'detoxification' processes ${ }^{3}$. Those who practice ayurveda believe detoxification will make these heavy metals non toxic. This process is done through complex processes, which involves simultaneous heating and cooling of the lead $>30$-times in a mixture containing buttermilk, cows urine and a mixture of three plants ${ }^{4}$. Unfortunately this process is unlikely to render heavy metals such as lead nontoxic, although they could influence bioavailability if combined with substances that chelated the metals by reducing absorption ${ }^{3}$.

Our study did not detect lead adulteration in those medicines which were selected for the study. This may be because of proper quality control from the concerned authorities assigned for the purpose or it may be the 
lesser sensitivity of testing due to use of flame mode instead of graphite furnace analysis.

There are many ways of lead intoxication in children. It is least talked about the ayurvedic products as potential source of lead despite its rampant use. The earliest reporting of lead intoxication by the use of aphrodisiacs was in $1978^{5}$.

Study by Saper RB et al in their study found $20 \%$ of ayurvedic herbal medicine products produced in South Asia contained potential harmful level of lead, arsenic and mercury ${ }^{6}$. In a similar kind of study done by Koch I et al, bioaccessible lead was found in in $72 \%$ of the 42 samples of traditional Indian medicines ${ }^{7}$.

Study by Jayawardene I et al looking in vitro bioaccessibility of lead, arsenic, cadmium and mercury in five traditional Indian medicine samples was measured as a determinant of bioavailability. When compared with the most liberal published safety guideline, EDAB$\mathrm{Pb}$ (estimated daily amount bioaccessible - lead) in Mahayograj Guggulu and Ekangvir Ras were 37 and 45 fold greater ${ }^{8}$.

\section{Conclusion}

There has been an issue of safety of ayurvedic medicines as these can be adulterated with heavy metals like lead. Though our study did not detect lead in the seventeen samples of ayurvedic medicine, a larger study is needed involving large samples of these medicines with use of graphite furnace analysis for testing. It is equally important to make people aware that ayurvedic medicines can be toxic and not always safe as we have reviewed several reported cases of high lead content in these drugs.

Acknowledgement: I am very thankful to Professor Puspa Raj Sharma who encouraged me to carry out this study. I would like to thank Mrs Jeevan Prabha Lama, Director at Department of Food Technology and Quality Control who agreed to test the ayurvedic products.
Funding: Department of Paediatrics, Kathmandu Medical College, Sinamangal

Conflict of Interest: None.

Disclaimer: This study was not done with the intention to promote or criticize any ayurvedic medicine companies and their products. It is a sincere effort to make doctors and health professionals aware about the possibility of adulteration of those medicines by lead if any.

\section{References}

1. Lynch E, Braithwaite R: A review of the clinical and toxological aspects of traditional (herbal) medicines adultered with heavy metals. Expert Opin Drug Saf 2005; 4(4):769-78.

2. David Beasley. Reuters Health Information. US lowers threshold for lead poisoining in children. [Cited 22 May 2012]. Available from: http://www. medscape.com/viewarticle/764009.

3. Ernst E. Heavy metals in traditional Indian remedies. Eur J Clin Pharmacol 2002; 57(12):891-96.

4. Thatte UM, Rege NN, Pathak SD, Dahanukar SA. The flip side of Ayurveda. J Postgrad Med 1993;39(4):179-82.

5. Brearley R, Foreythe A: Lead poisoning from aphrodisiacs: potential hazard in immigrants. $\mathrm{Br}$ Med J 1978;276:1748-49.

6. Saper RB, Kales SN, Paquin J, Burns MJ, Eisenberg DM, Davis RB, Phillips RS. Heavy metal content of ayurvedic herbal medicine products. JAMA 2004; 292(23):2868-73.

7. Koch I, Moriarty M, House K, Sui J, Cullen WR, Saper RB, Reimer KJ. Bioaccessibility of lead and arsenic in traditional Indian Medicines. Sci Total Environ 2001; 409(21):4545-52.

8. Jayawardene I, Saper R, Lupoli N, Sehgal A, Wright $\mathrm{RO}$, Amarasiriwardena $\mathrm{C}$. Determination of in vitro bioaccessibility of lead, arsenic, cadmium and mercury. J Anal At Spectrom 2010; 25(8):1275-82. 